\title{
Pemanfaatan Metode Fuzzy Analytical Network Process dalam Memilih Supplier dengan Mempertimbangkan Aspek Manajemen Organisasi
}

\section{The Use of Fuzzy Analytical Network Process Method in Selecting Suppliers by Considering Organizational Management Aspects}

\author{
Arif $\operatorname{Imran}^{1}$, Fadillah Ramadhan ${ }^{* 1}$, Muhammad Nugroho Nitisastra ${ }^{1}$ \\ ${ }^{1}$ Program Studi Teknik Industri, Fakultas Teknologi Industri, Institut Teknologi Nasional Bandung
}

ARTICLE INFO

Article history:

Diterima 10-12-2020

Diperbaiki 20-12-2020

Disetujui 29-12-2020

Kata Kunci:

Fuzzy-ANP, MCDM,

Manajemen Organisasi, Supplier.

\author{
AB S TR A K
}

Pemilihan supplier merupakan suatu aktivitas penting dalam kegiatan kolaborasi antar perusahaan. Perusahaan manufaktur harus memperhatikan seluruh aspek dari supplier dan bukan hanya melihat pada aspek yang melekat terhadap produk saja, melainkan aspek penting lainnya seperti aspek manajemen organisasi. Kapabilitas, reputasi, dan etika kerjasama supplier harus diperhatikan untuk menjaga konsistensi kolaborasi yang terjadi. Manajemen organisasi perusahaan supplier yang baik akan menciptakan suatu sistem yang reliabel dan berdampak pada peningkatakan kemampuan daya saing bagi perusahaan manufaktur ataupun supplier itu sendiri. Salah satu teknik pemilihan supplier yang dapat digunakan untuk menghasilkan solusi yang baik adalah metode Fuzzy Analytical Network Process (FANP). Metode tersebut dapat menghasilkan kualitas solusi yang tinggi, dimana tingkat subjektivitas dan ketidakakuratan yang terjadi dapat terminimalisir dibandingkan dengan metode ANP biasa. Pada penelitian ini, salah satu perusahaan manufaktur yang memprioritaskan manajemen organisasi sebagai aspek penting dalam kolaborasi supplier dijadikan objek penelitian. Dari hasil penelitian didapatkan urutan pemilihan prioritas supplier yang lebih komprehensif dan lebih baik dengan mempertimbangkan kriteria manajemen organisasi di dalamnya.

\section{A B S TR ACT}

Supplier selection is an important activity in collaborative processes between companies. Manufacturing companies must pay attention to all aspects of the supplier and not only look at the aspects inherent to the product, but other important aspects such as organizational management aspects. Capability, reputation, and supplier ethics must be considered to maintain consistency of collaboration. Good organizational management of the supplier company will create a reliable system and have an impact on increasing the competitiveness of the manufacturing company or the supplier itself. One of the supplier selection techniques that can be used to produce a good solution is the Fuzzy Analytical Network Process (F-ANP) method. This method can produce better quality solutions, where the level of subjectivity and inaccuracies that occur can be minimized compared to the usual ANP method. In this study, a manufacturing company that prioritizes organizational management as an important aspect of supplier collaboration is the research object. From the results, a more comprehensive and better supplier priority selection is obtained by considering the organizational management criteria.
Keywords:

Fuzzy-ANP, MCDM,

Organizational Management, Supplier perusahaan manufaktur tersebut biasanya adalah supplier, pabrik, distributor, toko atau ritel, serta perusahaanperusahaan pendukung lainnya seperti perusahaan jasa logistik [3]. Aktivitas yang terdapat dalam SCM diantaranya adalah proses pengiriman, transformasi bahan baku, dan procurement. Procurement merupakan salah satu aktivitas penting pada SCM, dimana proses tersebut berperan untuk 
mendapatkan barang dan pelayanan-pelayanan yang digunakan dalam proses produksi [4], [5]. Aktivitas yang terjadi dalam procurement salah satunya adalah pemilihan supplier. Dalam proses pemilihan supplier, harus dipertimbangkan berbagai kriteria yang dibutuhkan oleh pihak perusahaan yang melakukan proses pemilihan.

Pentingnya pemilihan supplier dalam kegiatan kolaborasi antar perusahaan telah dilakukan oleh beberapa penelitian sebelumnya. Lam dkk. [6] melakukan penelitian dalam menentukan pemilihan bahan baku supplier menggunakan fuzzy principal component analysis. Pada penelitian tersebut kriteria yang melekat pada bahan baku menjadi fokus utama dalam penentuan supplier. Penelitian sejenis lainnya dilakukan oleh Taherdoost \& Brard [7] yang lebih menonjolkan kriteria cost dan benefit dari produk yang akan dibeli. Selain itu, Wang dkk. [8] melakukan penelitian dalam menentukan pemilihan supplier optimal pengadaan produk baterai menggunakan metode fuzzy entropy. Pada penelitian tersebut kriteria komponen produk baterai menjadi kajian utama dalam proses penentuan prioritas.

Berdasarkan penelitian-penelitian sebelumnya tersebut, kriteria yang dipertimbangkan banyak terfokus pada produk yang dibeli atau cost dan benefit dari proses interaksi yang terjadi. Masih jarang yang mempertimbangkan aspek manajemen organisasi dalam menentukan supplier terbaik. Manajemen organisasi perusahaan supplier baik dari pengelolaan sistem perusahaan ataupun membuka kesempatan perusahaaan manufaktur untuk ikut terlibat langsung dalam proses pengembangan sistem perusahaan akan sangat bermanfaat dalam meningkatkan kualitas produk yang dihasilkan [9]. Selain kualitas produk yang baik, inovasi pengembangan produk dapat terjadi lebih mudah dengan adanya proses knowledge sharing dan kolaborasi antara perusahaan manufaktur dan supplier yang dapat meningkatkan keunggulan kompetitif semua pihak [10], [11]. Berdasarkan hal tersebut maka dibutuhkan proses penambahan kriteriakriteria yang terkait dengan manajemen organisasi yang dapat meningkatkan keakuratan dalam memilih supplier.

Pada penelitian ini, PT. Prakasa Triputra Solusi yang dalam aktivitasnya terfokus pada pencarian bahan baku dari supplier dijadikan objek penelitian. Perusahaan ini selalu melakukan penyeleksian supplier terbaik dalam menghasilkan kualitas bahan baku yang optimal untuk kegiatan produksi. Bahan baku yang dibutuhkan oleh perusahaan terdiri dari bahan baku utama berupa kulit sapi dan kulit sintetis/imitasi, serta bahan baku penunjang berupa tali dan eyelets. Dari segi bahan baku utama, kualitas kulit sapi dapat dinilai dari beberapa faktor seperti ketebalan kulit, corak dari kulit yang dihasilkan, dan tekstur dari kulit. Selain kriteria yang melekat pada produk seperti harga, kualitas, dan lead time, perusahaan mempertimbangkan juga proses manajemen organisasi supplier dan hubungan kolaborasi apa yang dapat dilakukan agar proses kerjasama dapat berlangsung dengan lama. Pada awalnya perusahaan tidak terfokus dalam proses kolaborasi jangka panjang, sehinga perusahaan terkadang sering melakukan penggantian supplier dan mengalami beberapa masalah yang berdampak pada laju produksi atau keterlambatan barang. Perusahaan memiliki keluhan mengenai waktu lead time yang tidak sesuai dan terkadang kualitas produk yang dihasilkan kurang baik. Agar tidak terjadi permasalahan tersebut diperlukan pendekatan lain yang dapat mempertimbangkan manajemen organisasi supplier untuk dapat dilakukannya kolaborasi aktivitas antar perusahaan.

Berdasarkan hal tersebut, maka penelitian ini bertujuan untuk mengembangkan kriteria-kriteria pemilihan supplier yang terdiri dari aspek yang melekat pada produk secara langsung dan aspek lain yang terkait dengan manajemen organisasi supplier. Selain itu, proses pemilihan supplier tersebut akan diimplementasikan pada objek penelitian dengan menggunakan Fuzzy Analytical Network Process (F-ANP). Metode tersebut dapat menghasilkan kualitas solusi yang lebih baik, dimana tingkat subjektivitas dan ketidakakuratan yang terjadi dapat terminimalisir dibandingkan metode ANP biasa. Dengan metode tersebut dapat dihasilkan urutan prioritas supplier optimal yang secara komprehensif telah mempertimbangkan berbagai kriteria yang diidentifikasi.

\section{Proses procurement dalam supply chain management}

Menurut the Council of Supply Chain Management Professional (CSCMP), SCM meliputi perencanaan dan pengelolaan seluruh aktivitas yang terlibat dalam sourcing and procurement, pengkorversian, dan seluruh aktivitas dalam manajemen logistik [3]. Selain itu, koordinasi dan kolaborasi antar pihak seperti para pemasok, perantara, para penyedia layanan pihak ketiga, dan pelanggan masih menjadi bagian dari ruang lingkup SCM yang intinya adalah mengintegrasikan pengelolaan supply dan demand antar perusahaan.

Salah satu aktivitas penting dalam SCM adalah proses procurement atau pengadaan yang memiliki tugas dalam menyediakan barang atau jasa yang diperlukan dalam kegiatan produksi atau kegiatan lain dari sebuah perusahaan [4]. Dalam sebuah perusahaan, bagian pengadaan akan menyediakan barang-barang yang dibutuhkan dan akan diklasifikasikan secara umum menjadi bahan baku dan komponen untuk kebutuhan produksi, capital equipment (mesin dan peralatan jangka panjang), alat-alat yang menunjang barang lainnya atau biasa dinamakan Maintenance, Repair, dan Operating Supplies (MRO) [3].

Memilih supplier merupakan sebuah kegiatan yang bersifat penting karena dapat digunakan dalam jangka waktu yang panjang. Dalam melakukan pemilihan supplier dibutuhkan proses identifikasi secara rinci dalam memilih kriteria-kriteria keputusan. Dickson [12] melakukan survei mengenai kriteria pemilihan supplier dan direspon oleh 170 manajer pembelian di Amerika Serikat, hasil dari penelitian tersebut dapat dilihat pada Tabel 1 yang berisikan mengenai kriteria pemilihan atau evaluasi supplier.

\section{Aspek manajemen organisasi dalam pemilihan supplier}

Manajemen organisasi perusahaan baik dari manajemen perusahaan supplier secara internal ataupun terkait dengan hubungan kolaborasi dengan perusahaan lain merupakan aspek penting dalam SCM. Hubungan kolaborasi antar perusahaan bisa dalam bentuk kolaborasi pengembangan produk atau hanya sebatas kolaborasi jual beli [13]. Hubungan kolaborasi antara perusahaan manufaktur dan supplier terkadang dibutuhkan dalam intensitas yang tinggi, termasuk dalam memberikan akses perusahaan manufaktur dalam 
mengelola beberapa kegiatan perusahaan supplier [10]. Dalam kolaborasi pengembangan produk, perusahaan manufaktur dan supplier terlibat langsung dalam tahapan perencanaan desain, pemilihan material, dan segala aktivitas penunjangnya sampai dengan proses produksi [14], [15]. Hal tersebut merupakan bagian dari manajemen organisasi antar perusahaan yang dapat meningkatkan keunggulan kompetitif semua pihak [14].

Tabel 1.

Kriteria Pemilihan dan Evaluasi Supplier

\begin{tabular}{cl}
\hline Skor & \\
\hline 3,5 & Quality \\
3,4 & Delivery a \\
3,0 & Performance history \\
2,8 & Waranties and claim policies \\
2,8 & Price \\
2,5 & Technical capability \\
2,5 & Financial position \\
2,5 & Compliance procedural \\
2,4 & Communication system \\
2,4 & Reputation and position in industry \\
2,3 & Desire for business \\
2,2 & Management and organization \\
2,2 & Operation controls \\
2,1 & Repair service \\
2,1 & Impression \\
2,0 & Packaging ability \\
2,0 & Labor relations records \\
1,9 & Geographical location \\
1,6 & Amount of past business \\
1,5 & Training aids \\
0,6 & Reciprocal arrangements \\
\end{tabular}

Manajemen organisasi internal perusahaan supplier ataupun pengendalian organisasi antar perusahaan dapat meningkatkan performansi perusahaan terutama dalam hubungan kerjasama jangka panjang. Pengendalian organisasi secar formal yang dilakukan oleh perusahaan manufaktur menjadi hal penting agar kualitas sistem dapat terjaga dengan baik [16]. Hubungan kolaborasi antara perusahaan manufaktur dan supplier dapat saling mengevaluasi kelemahan masingmasing perusahaan yang dapat berdampak pada perbaikan secara bersama-sama. Intensitas komunikasi yang tinggi antar perusahaan akan semakin meningkatkan berbagai kebijakan strategis yang dapat menguntungkan semua pihak [17]. Dengan demikian, sangat penting dalam mempertimbangkan kriteria yang terkait dengan proses manajemen organisasi perusahaan supplier dalam melakukan pemilihan prioritas supplier.

\section{Pemanfaatan F-ANP dalam pemilihan supplier}

F-ANP merupakan salah satu metode yang masuk kedalam bagian Multi Criteria Decision Making (MCDM). MCDM adalah suatu metode pengambilan keputusan yang digunakan untuk menentukan suatu alternatif solusi. Alternatif solusi tersebut terdiri dari beberapa kriteria ataupun sub kriteria yang menjadi landasan dalam pemilihan. Metode ini sangat dibutuhkan oleh decision maker dalam menentukan suatu pilihan apapun secara cepat, tepat, dan memiliki kualitas solusi yang tinggi [18].

F-ANP merupakan bentuk pengembangan dari Analytical Network Process (ANP). Menurut Saaty [19], terdapat dua metode umum dalam pengambilan keputusan, yaitu suatu pengambilan keputusan yang tekait dengan independent criteria yang biasa digunakan dengan metode Analytical Hierarchy Process (AHP) dan pengambilan keputusan yang bersifat dependent criteria atau memiliki ketergantungan yang erat. Untuk permasalahan dengan kriteria dependent tersebut, metode yang lebih sesuai untuk digunakan adalah metode ANP [20], [21]. Perbandingan berpasangan pada setiap data digunakan dalam pengolahan data dengan metode AHP maupun ANP. Dibutuhkan responden yang merupakan expert dari sistem yang dibahas dan mengisi nilai dari setiap perbandingan. Dengan ketergantungannya kedua metode tersebut terhadap keakuratan jawaban responden, maka AHP dan ANP memiliki kelemahan dari segi kualitas solusi, karena tingkat ketepatan dan kepastian responden dalam melakukan penilaian bisa terlalu subjektif. Menurut Hermawan dkk. [22] secara garis besar langkah-langkah dalam melakukan menggunakan metode ANP dimulai dari menentukan nilai matriks perbandingan berpasangan sampai dengan didapatkan bobot kriteria ataupun sub kriteria. Menurut Yalya \& Yilidz [23], ketika hasil dari bobot-bobot sudah diperoleh maka data tersebut dapat dimasukkan ke dalam software Super Decisions. Dari software tersebut dapat diperoleh data prioritas dari permasalahan yang ada. Data yang akan ditampilkan oleh software mulai dari data unweighted supermatrix hingga priorities dari permasalahan.

F-ANP merupakan metode gabungan dari Fuzzy dan ANP. Tahap awal dari metode ini adalah metode AHP yang dikembangkan menjadi ANP dengan tambahan interaksi umpan balik dari elemen-elemen baik inner dependence maupun outer dependence. Logika fuzzy merupakan logika yang digunakan dengan konsep dasar berupa kebenaran sebagian, dimana suatu logika yang menyatakan bahwa segala hal termasuk suatu nilai yang subjektif dapat diklasifikasikan atau diintrepretasikan dalam istilah binary [24].

Menurut Govindaraju \& Sinulingga [25] pada semesta $X$, himpunan fuzzy $A$ dinyatakan sebagai himpunan pasangan berurutan atau dikenal dengan set of ordered pairs. Nilai himpunan tersebut dapat bersifat diskrit maupun kontinu. Himpunan fuzzy $\check{A}$ dalam himpunan semesta $X$ yang diekspresikan dalam model matematis dapat dilihat pada persamaan berikut.

$\tilde{A}=\{(\mathrm{x}, \mu \check{A}(x) \mid x \in X$

Himpunan fuzzy yang dirancang tersebut dapat berupa Triangular Fuzzy Number atau dikenal dengan TFN yang dapat dinotasikan sebagai berikut:

$\tilde{A}=\left(l_{1}, m_{1}, u_{1}\right)$

Nilai $l, m$ dan $u$ yang berperan sebagai parameter menunjukkan nilai kemungkinan yang rendah, tengah, dan tinggi dari suatu aktivitas. Ada beberapa aturan operasi aritmatika TFN yang umum digunakan jika terdapat dua bilangan TFN $\tilde{A}_{1}=\left(l_{1}, m_{1}, u_{1}\right)$ dan $\tilde{A}_{2}=\left(l_{2}, m_{2}, u_{2}\right)$, yaitu sebagai berikut:

a. Penjumlahan dua bilangan fuzzy $\widetilde{\mathrm{A}}_{1}+\widetilde{\mathrm{A}}_{2}=\left(\mathrm{l}_{1}+\mathrm{l}_{1}, \mathrm{~m}_{1}+\mathrm{m}_{2}, \mathrm{u}_{1}+\mathrm{u}_{2}\right)$ 
b. Perkalian dua bilangan fuzzy

$\widetilde{\mathrm{A}}_{1} \times \widetilde{\mathrm{A}}_{2}=\left(\mathrm{l}_{1} \mathrm{l}_{1}, \mathrm{~m}_{1} \mathrm{~m}_{2}, \mathrm{u}_{1} \mathrm{u}_{2}\right)$

c. Perkalian bilangan real $\mathrm{r}$ dengan bilangan fuzzy $\mathrm{rx} \widetilde{\mathrm{A}}_{1}=\left(\mathrm{r} \mathrm{l}_{1}, \mathrm{r} \mathrm{m}_{1}, \mathrm{r} \mathrm{u}_{1}\right)$

d. Pengurangan dua bilangan fuzzy

$\widetilde{A}_{1}-\widetilde{A}_{2}=\left(\mathrm{l}_{1}-\mathrm{l}_{2}, \mathrm{~m}_{1}-\mathrm{m}_{2}, \mathrm{u}_{1}-\mathrm{u}_{2}\right)$

e. Pembagian dua bilangan fuzzy

$\widetilde{\mathrm{A}}_{1} / \widetilde{\mathrm{A}}_{2}=\left(\mathrm{l}_{1} / \mathrm{u}_{2}, \mathrm{~m}_{1} / \mathrm{m}_{2}, \mathrm{u}_{1} / \mathrm{l}_{2}\right)$

f. Respirokal bilangan fuzzy

$\widetilde{\mathrm{A}}_{1}^{-1}=1\left(1 / \mathrm{u}_{1}, 1 / \mathrm{m}_{1}, 1 / \mathrm{l}_{1}\right)$

untuk $l_{l}, m_{l}, u_{l}>0$

Berikut merupakan skala bilangan dari TFN yang dapat dilihat pada Tabel 2 .

Tabel 2.

Skala Bilangan Triangular Fuzzy Number (TFN)

\begin{tabular}{lll}
\hline Definisi & Skala Likert & TFN \\
\hline Sangat peting & 1 & $(1,1,3)$ \\
& 2 & $(1,2,4)$ \\
Sedikit lebih penting & 3 & $(1,3,5)$ \\
Lebih penting & 4 & $(2,4,6)$ \\
& 5 & $(3,5,7)$ \\
Sangat lebih penting & 6 & $(4,6,8)$ \\
Mutlak lebih penting & 8 & $(5,7,9)$ \\
& 9 & $(6,8,9)$ \\
\hline
\end{tabular}

Langkah-langkah metode F-ANP menurut Vinodh dkk. [26] adalah sebagai berikut:

a. Menghitung bobot kriteria tanpa ketergantungan $\left(W_{21}\right)$. Langkah-langkah mengitung bobot kriteria tersebut dapat dilihat dibawah ini.

- Mengubah matriks berpasangan yang sudah dibuat menjadi matriks perbandingan berpasangan fuzzy.

- Tahapan berikutnya adalah membuat matriks perbandingan berpasangan secara fuzzy gabungan. Jika jumlah responden lebih dari satu maka matriks dari perbandingan berpasangan akan lebih dari satu. Karena hal tersebut dapat dilakukan dengan rata-rata geometrik untuk menghasilkan matriks perbandingan berpasangan gabungan.

$\widehat{\mathrm{GT}}=\sum_{\mathrm{i}=1}^{\mathrm{k}} 1_{1}, \sum_{\mathrm{i}=1}^{\mathrm{k}} \mathrm{m}_{1}, \sum_{\mathrm{i}=1}^{\mathrm{k}} \mathrm{u}_{1}$

- Melakukan normalisasi terhadap matriks yang sebelumnya sudah terbentuk. Normalisasi dilakukan dengan rumus sebagai berikut.

$\widehat{\mathrm{W}}=\frac{\widehat{\epsilon}_{1}}{\widehat{C}_{T}}=\frac{l_{i}, m_{i}, u_{i}}{\sum_{i=1}^{k} 1_{1}, \sum_{i=1}^{k} m_{1}, \sum_{i=1}^{k} u_{1}}$

- Melakukan defuzzifikasi untuk mengembalikan nilai ke bobot nonfuzzy. Dengan melakukan persamaan berikut.

$$
\mathrm{DM}_{\mathrm{i}}=\frac{\mathrm{l}_{\mathrm{i}}+\mathrm{mi}_{\mathrm{i}}+\mathrm{l}_{\mathrm{i}}}{3}
$$

b. Menghitung bobot kriteria yang memiliki ketergantungan $\left(W_{22}\right)$. Proses perhitungan ini sama dengan perhitungan mencari bobot kriteria tanpa ketergantungan (langkah pertama). Perbedaan terletak pada kriteria yang dibandingkannya. Keseluruhan bobot kriteria yang memiliki ketergantungan menjadi input pada supermatriks.

c. Menghitung bobot keseluruhan.

Bobot keseluruhan ini dapat dihitung dengan cara melakukan rumus dibawah ini.

$$
W_{i}=W_{\text {kriteria }}=W_{21} x W_{21}
$$

\section{Metode Penelitian}

Metode penelitian menjabarkan tahapan yang dilakukan mulai dari tahap awal hingga tahap akhir penelitian. Penjelasan proses-proses penelitian diuraikan setiap kegiatan yang dilakukan. Metode penelitian dapat dilihat pada poinpoin sebagai berikut.

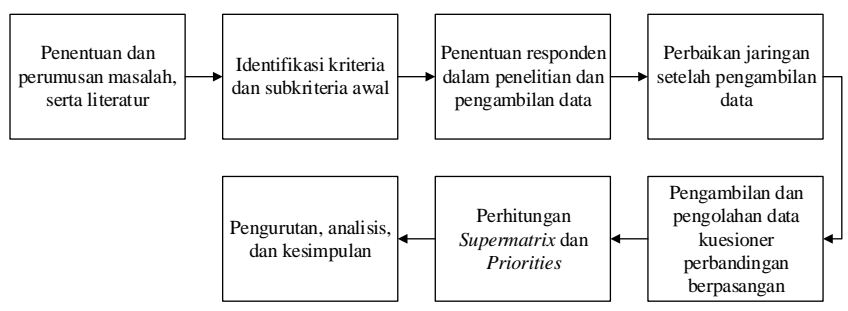

Gambar 1 Alur dari metode penelitian

Tahap 1: Merumuskan permasalahan yang terjadi pada sebuah perusahaan yang melakukan kesalahan dalam proses pemilihan supplier sebagai dampak dari tidak dipertimbangkannya aspek manajemen organisasi dalam aktivitas pemilihan.

Tahap 2: Mengidentifikasi kriteria dan subkriteria awal yang relevan digunakan dalam penelitian yang terkait dengan aspek yang melekat pada produk dan aspek manajemen organisasi supplier, serta membuat kriteria dan subkriteria tersebut ke dalam jaringan awal. Jaringan awal yang sudah dibuat menjadi bahan untuk pembuatan kuesioner pendahuluan yang berisikan validasi kriteria dan subkriteria awal kepada pihak perusahaan. Selain itu, dalam kuesioner tersebut terdapat input untuk mengidentifikasi ketergantungan subkriteria. Kuesioner ini bersifat terbuka yang artinya pihak perusahaan dapat menambahkan atau mengurangi kriteria yang ada.

Tahap 3: Menentukan responden dalam penelitian. Responden yang dipilih adalah orang-orang yang berkaitan dalam penentuan supplier yang akan dipilih. Setelah didapatkan responden yang akan terlibat dalam penelitian, dilakukan pengambilan data dari kuesioner pendahuluan yang telah dirancang. 
Tahap 4: Perbaikan jaringan dilakukan berdasarkan data dari kuesioner pendahuluan. Jaringan yang dibuat pada tahap ini akan menjadi input pembuatan kuesioner perbandingan berpasangan. Setelah kuesioner perbandingan berpasangan selesai, kuesioner tersebut diberikan kepada pihak perusahaan yang menjadi responden dalam penelitian ini.

Tahap 5: Melakukan perekapan data yang didapat dari kuesioner perbandingan berpasangan. Pada tahap ini, dilakukan perhitungan pembobotan ANP dan transformasi nilai ke TFN samapi dengan perhitungan konsisntensinya. Data dikatakan konsisten jika nilai rasio konsistensi dibawah 10\%. Apabila terdapat data yang tidak konsisten dilakukan proses pengisian kuesioner perbandingan berpasangan ulang.

Tahap 6: Melakukan proses perhitungan supermatrix, yaitu unweighted supermatrix, weighted supermatrix, dan limit supermatrix sebagai perhitungan awal dalam penentuan urutan prioritas supplier. Software Super Decisions akan digunakan untuk melakukan proses perhitungan pada tahap ini.

Tahap 7: Melakukan pembuatan ranking supplier, serta melakukan analisis dan penarikan kesimpulan dari perhitungan yang telah dilakukan dalam penelitian.

\section{Hasil dan Pembahasan}

Pada tahap awal, kriteria didapatkan berdasarkan literatur. Kriteria-kriteria tersebut berhubungan dengan pemilihan supplier yang sesuai dengan penelitian. Kriteria umum yang digunakan didapatkan berdasarkan Dickson [12]. Setelah didapatkan referensi kriteria yang akan digunakan dalam penelitian, dilakukan proses wawancara terhadap expert pada perusahaan yang dijadikan obek penelitian dibagian pengadaan barang divisi material. Wawancara tersebut dilakukan untuk mencari kriteria-kriteria yang sangat berpengaruh terhadap pemilihan supplier. Beberapa kriteria menurut Dickson [12] dihilangkan karena dari hasil wawancara terdapat beberapa kriteria yang kurang sesuai dengan kasus yang dialami perusahaan. Kriteria yang didapatkan dari hasil wawancara beserta penggabungannya dapat dilihat pada Tabel 3 .

Tabel 3.

Kriteria Gabungan

\begin{tabular}{ll}
\hline Kriteria terpilih & Kriteria hasil gabungan \\
\hline Price & Cost \\
Delivery & Cycle time \\
Financial position & \\
$\begin{array}{l}\text { Communication system } \\
\text { Operating controls }\end{array}$ & Hubungan \\
Impression & \\
Quality & Kualitas \\
Technical capability & \\
Compliance procedural & \\
Reputation and position in & \\
industry & \\
Management and organization & Organization \\
Attitudes & \\
Geographical location & \\
\hline
\end{tabular}

Setelah perbaikan kriteria yang bersumber dari literatur, pihak perusahaan menambahkan kriteria pelayanan untuk digunakan dalam pemilihan supplier. Setelah didapatkan kriteria dan subkriteria yang akan digunakan dalam penelitian, diberikan kuesioner pendahuluan yang berisikan validasi kriteria dan subkriteria yang menjadi acuan dalam penelitian dan keterkaitan antar subkriteria. Kuesioner pendahuluan tersebut diberikan kepada responden yang terkait dalam pengambilan keputusan pemilihan supplier. Pada penelitian ini responden merupakan expert di bagian divisi material yang berjumlah empat orang. Didapatkan kriteria dan subkriteria yang digunakan dalam penelitian yang dapat dilihat pada Tabel 4.

Tabel 4.

Kriteria dan Subkriteria

\begin{tabular}{ll}
\hline Kriteria & Subkriteria \\
\hline \multirow{3}{*}{ Kualitas (A) } & Fleksibilitas dalam operasi (A1) \\
& Sesuai dengan standar (A2) \\
& Konsistensi kualitas (A3) \\
& Reaksi terhadap permintaan (B1) \\
Pelayanan (B) & Kemampuan modifikasi produk (B2) \\
& Dukungan teknis (B3) \\
& After sales service (B4) \\
& Current technology (C1) \\
Organization (C) & Geographic location (C2) \\
& Innoavtioveness (C3) \\
& Compatibility of buyer firm (D1) \\
Hubungan & Kemampuan untuk identifikasi \\
& kebutuhan (D2) \\
Cycle time (E) & Ketersediaan (D3) \\
& Lead time pengiriman (E1) \\
Cost (F) & Harga bahan baku (F1) \\
& Konsistensi harga (F2) \\
& Negosiasi harga (F3) \\
\hline
\end{tabular}

Hasil dari penelitian yang dilakukan terdapat 6 kriteria dan 18 subkriteria. Aspek yang terkait dengan manajemen organisasi dan kolaborasi supplier dari hasil wawancara dan kuesioner didapatkan dua kriteria, yaitu kriteria organization dan hubungan. Kriteria organisasi terdiri dari manajemen teknologi yang dilakukan oleh supplier, tingkat inovasi yang dilakukan, dan tingkat kesesuaian organisasi dengan pihak pembeli yang merupakan perusahaan manufaktur. Dari segi kriteria hubungan, diidentifikasi dua sub kriteria yang terdiri dari kemampuan untuk mengidentifikasi kebutuhan dan ketersediaan pemenuhan kebutuhan yang dapat dilakukan dengan proses kolaborasi.

Dalam kuesioner pendahuluan didapatkan keterkaitan antar subkriteria yang menjadi acuan pembuatan jaringan ANP. Hasil keterkaitan tersebut dapat dilihat pada Gambar 2. Data yang dianggap memiliki ketergantungan jika nilai kuesioner tersebut lebih besar atau sama dengan setengah jumlah responden [3]. Setelah didapatkan hasil keterkaitan subkriteria, dilakukan pembuatan jaringan ANP yang menjadi acuan dalam pembuatan kuesioner perbandingan berpasangan yang akan diberikan kepada responden. 


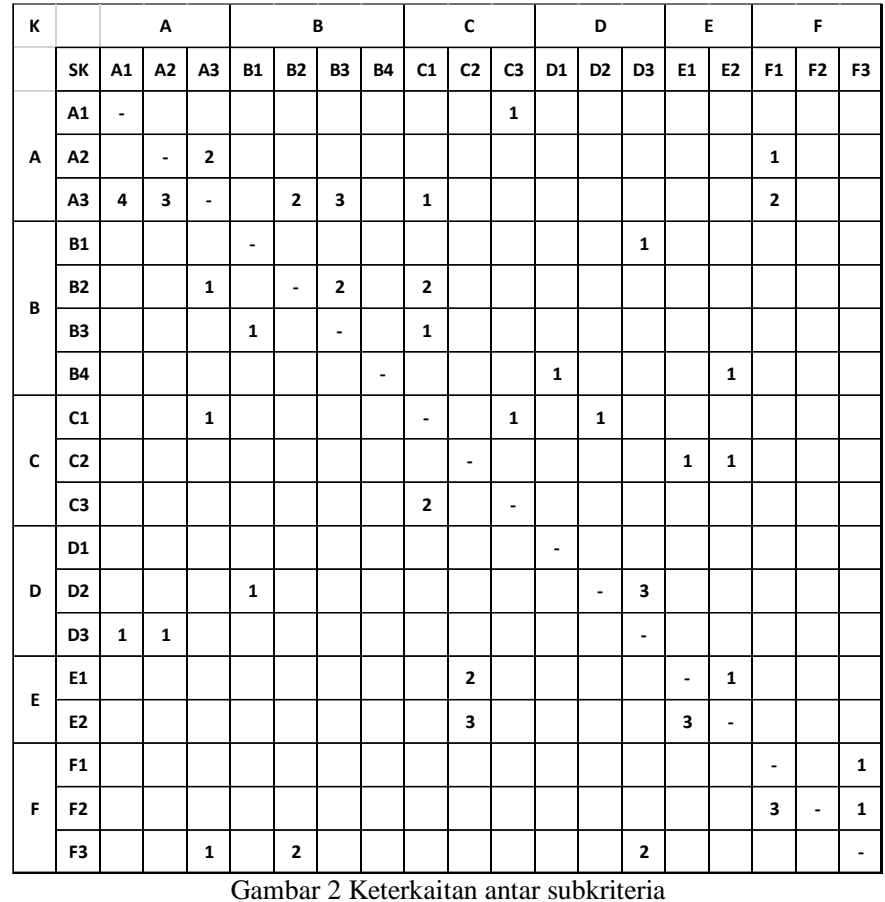

Setelah didapatkan data kuesioner perbandingan berpasangan, dilakukan perhitungan proses pembobotan menurut skala yang digunakan. Kemudian transformasikan data yang sudah didapatkan menjadi bilangan TFN pada setiap kolom. Bilangan TFN memiliki tiga nilai yaitu nilai rendah $(1)$, nilai tengah $(m)$, dan nilai atas $(u)$. Karena penelitian dilakukan lebih dari satu responden maka dilakukan perhitungan rata-rata geometri untuk merubah yang awalnya empat data menjadi satu data. Rumus rata-rata geometri dapat dilihat pada persamaan 13. Data hasil perhitungan rata-rata geometri dapat dilihat pada Tabel 5.

Rata-rata geometri $=\sqrt[k]{n_{1} \times n_{2} x \ldots x n_{k}}$

Tabel 5.

Hasil Perhitungan Rata-Rata Geometri

\begin{tabular}{cccccccccc}
\hline \multirow{2}{*}{ Kriteria } & \multicolumn{3}{c}{$\mathrm{F}$} & \multicolumn{4}{c}{$\mathrm{E}$} & \multicolumn{3}{c}{$\mathrm{D}$} \\
\cline { 2 - 10 } & $\mathrm{l}$ & $\mathrm{m}$ & $\mathrm{u}$ & 1 & $\mathrm{~m}$ & $\mathrm{u}$ & 1 & $\mathrm{~m}$ & $\mathrm{u}$ \\
\hline $\mathrm{F}$ & 1 & 1 & 1 & 1 & 1 & 3 & 1.316 & 3.409 & 5.439 \\
$\mathrm{E}$ & & & & 1 & 1 & 1 & 1 & 1 & 3 \\
$\mathrm{D}$ & & & & & & & 1 & 1 & 1 \\
\hline
\end{tabular}

Setelah didapatkan nilai perhitungan rata-rata geometri dilakukan perhitungan defuzzifikasi yang bertujuan merubah nilai TFN menjadi bilangan crisp. Kemudian setelah didapatkan nilai defuzzifikasi untuk kolom yang berlawanan diisi dengan nilai hasil pembagian satu dengan nilai kolom tersebut. Data defuzzifikasi dapat dilihat pada Tabel 6 .

Langkah selanjutnya, dilakukan proses perhitungan nilai bobot atau eigenvector. Cara untuk mencari nilai bobot tersebut dilakukan beberapa perhitungan yaitu menghitung jumlah matriks perbandingan, menghitung normalisasi, dan mengitung bobot tersebut. Data bobot seluruh kriteria dapat dilihat pada Tabel 7 .
Tabel 6.

Hasil Defuzzifikasi

\begin{tabular}{cccc}
\hline & $F$ & $E$ & $D$ \\
\hline$F$ & 1.000 & 1.667 & 3.388 \\
$E$ & 0.600 & 1.000 & 1.667 \\
\hline
\end{tabular}

Tabel 7.

Bobot Kriteria

\begin{tabular}{ll}
\hline Kriteria & Bobot \\
\hline Cost (F) & 0.3159 \\
Cycle Time (E) & 0.2375 \\
Hubungan (D) & 0.1145 \\
Kualitas (A) & 0.1887 \\
Organization (C) & 0.0808 \\
Pelayanan (B) & 0.0626 \\
\hline
\end{tabular}

Pada langkah selanjutnya, dilakukan perhitungan nilai rasio konsistensi dengan menghitung nilai $\lambda$ maks terlebih dahulu dan menghitung nilai rasio konsistensi. Berikut merupakan contoh perhitungan indeks konsistensi yang dapat dilihat dibawah ini.

$\lambda$ maks

$$
\begin{aligned}
& =\frac{\text { Ehasil pembagian penjumlahan dengan bobot }}{\text { nilai ordo }} \\
& \text { si } \quad=\frac{\lambda \text { maks }-\mathrm{n}}{n-1}
\end{aligned}
$$

Perhitungan nilai rasio konsistensi dilakukan dengan membagi nilai indeks konsistensi dengan nilai acak rasio indeks. Nilai rasio konsistensi dikatakan konsiten ketika nilai CR kurang dari $10 \%$.

$$
\text { Nilai Rasio Konsistensi }(C R)=\frac{G I}{R I}
$$

Nilai indeks acak (RI) untuk setiap matriks berorde satu sampai Sembilan dapat dilihat pada Tabel 8 [27].

Tabel 8 .

Nilai Indeks Acak

\begin{tabular}{cc}
\hline Orde & RI \\
\hline 1 & 0 \\
2 & 0 \\
3 & 0.52 \\
4 & 0.89 \\
5 & 1.11 \\
6 & 1.25 \\
7 & 1.35 \\
8 & 1.4 \\
9 & 1.45 \\
10 & 1.49 \\
\hline
\end{tabular}

Ketika hasil dari bobot-bobot sudah diperoleh maka data tersebut dapat dimasukkan ke dalam software Super Decisions. Dari software tersebut dapat diperoleh data prioritas dari permasalahan yang ada. Data yang akan ditampilkan oleh software mulai dari data unweighted supermatrix hingga priorities dari permasalahan. Supermatrix tidak tertimbang pada komponen ini diperoleh dari nilai-nilai perbandingan berpasangan antar cluster, kriteria, dan alternatif dengan melakukan penginputan nilai bobot lokal ke dalam matriks yang sesuai dengan selnya. Perhitungan supermatrix ini dilakukan pengolahan data dapat menggunakan software Super Decisions. 
Perhitungan komponen supermatrix tertimbang didapatkan berdasarkan hasil output software Super Decisions. Weighthed supermatrix didapatkan dari perkalian antara nilai unweighted supermatix pada setiap elemen dan komponen cluster matrix yang diperoleh dari Super Decisions. Matriks klaster terbentuk dari matriks atau tabel perbandingan berpasangan dengan keterkaitan antar klaster induk. Limit supermatriks diperoleh dari Super Decisions yang bertujuan untuk meningkatkan nilai supermatrix tertimbang hingga memperoleh nilai yang stabil. Artinya seluruh kolom pada sebuah matriks bernilai yang sama. Cara untuk memperoleh nilai tersebut dengan melakukan perkalian matriks tersebut dengan matriks itu sendiri. Perkalian dilakukan hingga seluruh kolom memiliki nilai yang sama. Setelah didapatkan hasil perhitungan matriks dilakukan pengurutan kriteria, subkriteria, dan supplier secara masing-masing. Data pengurutan kriteria dapat dilihat pada Tabel 9. Data pengurutan subkriteria dapat dilihat pada Tabel 10. Data pengurutan supplier dapat dilihat pada Tabel 11.

Tabel 9.

Ranking Kriteria

\begin{tabular}{llc}
\hline Kriteria & Bobot & Ranking \\
\hline Kualitas (A) & 0.4610 & 1 \\
Cost (F) & 0.2473 & 2 \\
Cycle Time (E) & 0.1355 & 3 \\
Hubungan (D) & 0.0650 & 4 \\
Organization (C) & 0.0473 & 5 \\
Pelayanan (B) & 0.0439 & 6 \\
\hline
\end{tabular}

Tabel 10.

Ranking Subkriteria

\begin{tabular}{lcc}
\hline \multicolumn{1}{c}{ Subkriteria } & Bobot & Ranking \\
\hline Konsistensi kualitas (A3) & 0.2241 & 1 \\
Sesuai dengan standar (A2) & 0.1795 & 2 \\
Konsistensi harga (F2) & 0.1137 & 3 \\
Harga bahan baku (F1) & 0.1025 & 4 \\
Lead time pengiriman (E1) & 0.0748 & 5 \\
Development speed (E2) & 0.0607 & 6 \\
Fleksibilitas dalam operasi (A1) & 0.0574 & 7 \\
Negosiasi harga (F3) & 0.0310 & 8 \\
Ketersediaan (D3) & 0.0275 & 9 \\
Geographic location (C2) & 0.0254 & 10 \\
Kemampuan untuk identifikasi kebutuhan (D2) & 0.0220 & 11 \\
Compability of buyer firm (D1) & 0.0155 & 12 \\
Kemampuan modifikasi produk (B2) & 0.0129 & 13 \\
Dukungan teknis (B3) & 0.0113 & 14 \\
Innovativeness (C3) & 0.0113 & 15 \\
Current Technology (C1) & 0.0106 & 16 \\
Reaksi terhadap permintaan (B1) & 0.0105 & 17 \\
After sales service (B4) & 0.0091 & 18 \\
\hline & & \\
\hline
\end{tabular}

Tabel 11. Ranking Supplier

\begin{tabular}{ccc} 
Supplier & Bobot & Ranking \\
Supplier 1 & 0.3919 & 1 \\
Supplier 4 & 0.2205 & 2 \\
Supplier 3 & 0.2079 & 3 \\
Supplier 2 & 0.1797 & 4 \\
\hline
\end{tabular}

Seluruh bobot kriteria pada umumnya digunakan sebagai pedoman dalam menentukan pemilihan supplier bahan baku. Semakin besar nilai bobot suatu kriteria maka akan semakin besar tingkat prioritas dan pengaruh terhadap pemilihan supplier ini. Angka dari bobot kriteria yang dihasilkan menunjukkan tingkat pengaruh terhadap pemilihan supplier menurut para responden.

Jumlah kriteria dalam penelitian ini adalah enam buah yang terdiri atas: kualitas, pelayanan, organization, hubungan, cycle time, dan cost. Seluruh kriteria tersebut setelah dilakukan penelitian menunjukkan besaran bobotnya masingmasing. Kriteria yang menduduki urutan pertama adalah kriteria kualitas dengan nilai bobot sebesar 0,4610. Hal tersebut menginformasikan bahwa pengaruh atau peran kriteria kualitas sebesar $46,10 \%$ bagi para responden. Kriteria kualitas menjadi hal penting dalam pemilihan supplier dan hal ini sesuai dengan penelitian-penelitian sejenis sebelumnya yang menjelaskan bahwa kualitas merupakan salah satu aspek penting dibandingkan kriteria lainnya [28], [29].

Berdasarkan hasil pengolahan data yang dilakukan oleh peneliti mendapatkan hasil ranking. Hasil ranking menunjukkan urutan pertama adalah supplier 1 dengan bobot sebesar 0,3919, urutan kedua adalah supplier 4 yang memiliki bobot sebesar 0,2205, kemudian dilanjutkan dengan supplier 3 yang memiliki nilai bobot sebesar 0,2079 , dan yang menjadi urutan keempat atau terakhir adalah supplier 4 dengan nilai bobot 0,1797. Setelah dilakukan validasi dengan pihak perusahaan lebih lanjut bahwa supplier 1 memiliki keunggulan dalam kriteria kualitas, cost, hubungan, dan pelayanan. Hal tersebut sesuai dengan hasil dari perhitungan pada penelitian. Pada kondisi nyata dalam beberapa waktu terkahir, supplier 1 memiliki nilai keunggulan dalam menyediakan kualitas dan cost bahan baku kulit untuk perusahaan.

Setiap supplier memiliki kelemahan dan kelebihannya masing-masing. Supplier 1 berlokasi di kota Cianjur, sehingga jika perusahaan ingin memenuhi permintaan yang secara mendadak tidak akan dapat terpenuhi oleh supplier 1. Maka dari itu, untuk menanggulangi permasalahan tersebut perusahaan dapat mencari alternatif lain yang memiliki jarak paling kecil dari perusahaan dan memiliki ketersediaan yang baik. Contoh supplier yang memiliki jarak paling kecil adalah supplier 3 dimana lokasinya berada di dekat perusahaan. Akan tetapi harga yang ditawarkan mahal karena supplier 3 ini berupa toko dan bukan pabrik.

Perusahaan harus mempertimbangkan segala kelemahan dari supplier yang terpilih dengan melihat kelebihan dan kekurangan dari keputusan yang diambil. Apabila supplier terpilih tidak bisa memenuhi permintaan dari keinginan perusahaan maka dapat digunakan ketiga alternatif lainnya yang dapat menyediakan kebutuhannya. 
Dengan demikian, implikasi manajerial dari hasil penelitian ini adalah PT. Prakasa Triputra Solusi sebagai perusahaan yang bertugas untuk melakukan pemilihan supplier disarankan untuk memilih supplier 1 sebagai pemasok bahan baku kegiatan produksinya. Supplier 1 cukup signifikan jauh lebih baik dari segi kriteria secara keseluruhan dibandingkan dengan pesaing lainnya, sehingga keputusan untuk memilih supplier tersebut sangatlah tepat. Selain itu, dari segi kriteria dan sub kriteria pun secara konsisten terkait dengan kualitas, sehingga supplier 1 langsung memiliki keterkaitan yang erat dengan tingkat kualitas yang jauh lebih baik dibandingkan alternatif lainnya. Aspek kualitas sangatlah penting dan hal yang utama sebagai output dari hasil kolaborasi baik antar perusahaan. Maka dari itu, PT. Prakarsa Triputra Solusi diharapkan bisa menjalin kerjasama yang baik dengan supplier 1 sekaligus membina konsistensi supplier baik dalam bentuk pelatihan, melibatkan kegiatan perencanaan produksi secara bersama, atau pengembangan inovasi produk secara kolaborasi dapat dilakukan untuk terciptanya peningkatan kualitas daya saing secara keseluruhan.

\section{Kesimpulan}

Penelitian ini bertujuan untuk melakukan pemilihan supplier berdasarkan kriteria yang terkait dengan aspek produk dan aspek manajemen organisasi menggunakan FANP. Dari hasil yang didapatkan, perusahaan dianjurkan memilih supplier 1 sebagai pemasok bahan baku kulit sapi untuk perusahaan. Jika dirasa terdapat kekurangan pada supplier 1 dapat dilakukan pemilihan supplier lebih dari satu sebagai pelengkap untuk menutupi kekurangan supplier utama dan mempertimbangkan keunggulan dan kelemahan dari setiap supplier. Selain itu, perusahaan harus memiliki komunikasi yang baik dengan para supplier karena dari hal tersebut perusahaan dapat meminimalisir masalah-masalah yang memungkinkan untuk terjadi dan sebagai aktivitas penting dalam aspek manajemen organisasi antar perusahaan.

Penelitian ini masih memiliki keterbatasan, dimana proses pengolahan belum dapat dilakukan secara dinamis jika kriteria yang ada berubah dengan cepat. Dengan demikian, untuk penelitian ini dapat dikembangkan dengan merancang sistem informasi pendukung keputusan yang lebih dinamis untuk mengakomodir kecepatan perubahan kriteria. Selain itu, beberapa metode lain yang memepertimbangkan data kuantitatif seperti Data Envelopment Analysis dapat diintegrasikan untuk mengakomodir keakuratan kriteria yang digunakan.

\section{Referensi}

[1] R. Krishnan, P. Yen, R. Agarwal, K. Arshinder, and C. Bajada, "Collaborative innovation and sustainability in the food supply chain-evidence from farmer producer organisations," Resour. Conserv. Recycl., 2020.

[2] D. Asamoah, B. Agyei-Owusu, F. K. Andoh-Baidoo, and E. Ayaburi, "Inter-organizational systems use and supply chain performance: Mediating role of supply chain capabilities," Int. J. Inf. Manage., 2020.

[3] I. N. Pujawan and E. M. Mahendrawathi, Supply Chain Management. Andi, 2017.
[4] G. Merckx and A. Chatuvedi, "Short vs. long-term procurement contracts when supplier can invest in cost reduction," Int. J. Prod. Econ., vol. 227, 2020.

[5] J.-T. Wong, "Dynamic procurement risk management with supplier selection and order allocation under green market segmentation," J. Clean. Prod., vol. 253, 2020.

[6] K.-C. Lam, R. Tao, and M. C.-K. Lam, "A material supplier selection model for property developers using Fuzzy Principal Component Analysis," Autom. Constr., vol. 19, no. 5, 2010.

[7] H. Taherdoost and A. Brard, "Analyzing the process of supplier selection criteria and methods," in Procedia Manufacturing, 2019.

[8] R. Wang, X. Li, and C. Li, "Optimal selection of sustainable battery supplier for battery swapping station based on triangular fuzzy entropyMULTIMOORA method," J. Energy Storage, 2020.

[9] B. J. W. C., C. Prahinski, and Y. Fan, "The influence of supplier development programs on supplier performance," Int. J. Prod. Econ., vol. 230, 2020.

[10] F. Ramadhan and T. M. A. A. Samadhi, "Interorganizational trust and knowledge sharing model between manufacturer and supplier in the automotive industry."

[11] J. Chang, "The effects of buyer-supplier's collaboration on knowledge and product innovation," Ind. Mark. Manag., vol. 65, pp. 129-143, 2017.

[12] G. W. Dickson, "An analysis of vendor selection systems and decisions," J. Purch., vol. 2, no. 1, 1966.

[13] J. H. Cheng and Y. C. Fu, "Inter-organizational relationships and knowledge sharing through the relationship and institutional orientations in supply chains," Int. J. Inf. Manage., vol. 33, no. 3, 2013.

[14] B. Lawson, K. J. Petersen, P. D. Cousins, and R. B. Handfield, "Knowledge sharing in interorganizational product development teams: The effect of formal and informal socialization mechanisms," J. Prod. Innov. Manag., vol. 26, pp. 156-172, 2009.

[15] M. A. L. Dain and V. Merminod, "A knowledge sharing framework for black, grey, and white box supplier configurations in new product development,' Technovation, vol. 34, pp. 688-701, 2014.

[16] E. Pernot and F. Roodhooft, "The impact of interorganizational management control systems on performance: A retrospective case study of an automotive supplier relationship," Int. J. Prod. Econ., vol. 158, pp. 156-170, 2014.

[17] A. Paulraj, A. A. Lado, and I. J. Chen, "Interorganizational communication as a relational competency: Antecedents and performance outcomes in collaborative buyer-supplier relationships," J. Oper. Manag., vol. 26, no. 1, pp. 45-64, 2008.

[18] T. Rochman, "Pemilihan rancangan roda gigi berdasarkan karakteristik material dengan metode ELECTRE," J. Tek. Ind., vol. 16, no. 1, pp. 15-25, 2017.

[19] T. L. Saaty, "Decision making with the analytical hierarchy process," Int. J. Serv. Sci., vol. 1, no. 1, 2008. 
[20] A. Wardhana, "Perancangan integrasi sistem penilaian kinerja supplier dengan metode DELPHI, DEMATEL, ANP, dan TLS pada PT. ME Engineering," $J$. Rekayasa Sist. Ind., vol. 1, no. 152-159, 2014.

[21] U. Wilan, "Identifikasi key position dengan metode AHP dan kriteria profil kompetensi talent key position pada PT. Industri Telekomunikasi Indonesia," $J$. Rekayasa Sist. Ind., vol. 1, no. 1, pp. 31-36, 2014.

[22] F. D. Hermawan, R. Saptono, and R. Anggrainingsih, "Modifikasi Analytic Network Process (ANP) untuk rekomendasi pemilihan handphone," J. Teknol. dan Inf., vol. 3, no. 2, 2014.

[23] A. Y. Yalya and A. Yilidz, "Fuzzy Analytic Network Process based Multi Criteria Decision Making," South African J. Ind. Eng., vol. 21, no. 2, pp. 167-180, 2013.

[24] R. Ardiansyah, R. N. Hasanah, and M. A. Muslim, "Analisis metode Fuzzy Aalytical Network Process untuk sistem pengambilan keputusan pemeliharaan jalan," JNTETI, vol. 5, no. 2, 2016.

[25] R. Govindaraju and J. P. Sinulingga, "Pengambilan kepututsan pemilihan pemasok di perusahaan manufaktur dengan metode Fuzzy-ANP," J. Manaj. Teknol., vol. 16, no. 1, pp. 1-16, 2017.

[26] S. Vinodh, R. A. Ramiya, and S. G. Gautham, "Application of fuzzy analytical network process for supplier selection in a manufacturing organisation," Tamil Nadu, India, 2011

[27] F. Sari and I. Sensuse, "Penerapan metode analytical hierarchy process dalam sistem penunjang keputusan," J. Sist. Inf., vol. 4, no. 2, 2012.

[28] Ngatawi and I. Setyaningsih, "Analisis pemilihan supplier menggunakan metode AHP," J. Ilm. Tek. Ind., vol. 10, no. 1, pp. 7-13, 2011.

[29] L. Merry, M. Ginting, and B. Marpaung, "Pemilihan supplier buah dengan pendekatan analytical hierarchy process dan TOPSIS: Studi kasus pada perusahaan retail," J. Tek. dan Ilmu Komput., vol. 3, no. 9, pp. 4858,2014 